\title{
Detection of microbial proliferation \& assessment of antibacterial activity of spices collected from various locations of Dhaka city, Bangladesh
}

\author{
Md. Aftab Uddin*, Khondakar Wahid Hasan and Jubaida Binta Jamal \\ Department of Microbiology, Stamford University Bangladesh, 51 Siddeswari Road, Dhaka 1217, Bangladesh
}

Received 04 April 2017/Accepted 13 May 2017

\begin{abstract}
The current study was aimed to detect the presence of contaminating microorganisms in some commonly available spices collected from different areas of Dhaka city, Bangladesh and also to assess their antibacterial activity. Out of eight samples under this study, total viable bacterial count (TVBC) was observed within the range of $10^{6}$ to $10^{7} \mathrm{cfu} / \mathrm{g}$. Among the specific bacterial isolates Staphylococcus spp., Pseudomonas spp. and Escherichia coli were found in almost all the samples within the margin of $10^{2}$ to $10^{6} \mathrm{cfu} / \mathrm{g}$. Alarmingly Salmonella spp. and Vibrio spp. were presumptively identified in one and two samples respectively. Besides every sample showed the presence of fungus with load up to $10^{3}$ cfu/g. Antibacterial activity of these samples was tested against seven laboratory isolates. Syzygium aromaticum showed highest activity against as many as five bacterial isolates while Cinnamomum verum was active against four isolates. On the other contrary, both Zingiber officinale and Laurus nobilis demonstrated their antibacterial activity only against Staphylococcus spp. and Klebsiella spp. respectively.
\end{abstract}

Key words: Antibacterial activity; Syzygium aromaticum; Cinnamomum verum; Zingiber officinale; Laurus nobilis

Spices are substances collected from indigenous or exotic plan origin, having distinct aroma or strong taste, used for the enhancement of the taste of foods. Spices include leaves (bay, mint, rosemary, laurel and oregano), flowers (Syzygium aromaticum), bulbs (garlic, onion), stems (coriander, Cinnamomum verum), rhizomes (Zingiber officinale), fruits (red chilli, cumin, black pepper), and other plant parts (1). Although, spices have been well known for their medicinal, antioxidant as well as preservative properties, they have been currently used with primary purpose of enhancing the flavor of foods rather than extending shelf-life. Spices active compounds have been included in class of naturally occurring food preservatives and have their inclusion in foods allowed by food production regulator offices. Several scientific reports describe the inhibitory effect of spices on a variety of microorganisms, although considerable variation for resistance of different microorganisms to a given spice and of the same microorganisms to different spices has been observed $(1,2)$.

One of the most important determinants of food is the appearance of its appeal to consumers and subsequently, sales of the product. Loosing food value and reduction of shelf life can be caused by microbial contamination. The most common bacteria causing

*Corresponding Author: Mailing address. Md. Aftab Uddin, Assistant Professor, Department of Microbiology, Stamford University Bangladesh, 51 Siddeswari Road, Dhaka 1217, Bangladesh, Bangladesh; E-mail: aftab_mb12@yahoo.com. food-borne illness are Escherichia coli, Salmonella spp., Salmonella typhimurium, Listeria monocytogenes, Staphylococcus aureus, Clostridium botulinum, Vibrio vulnificus, Vibrio parahaemolyticus and others (3). Spices may be contaminated because of the surroundings under which they were cultivated and harvested. Spice such as contaminated Syzygium aromaticum has been reported to have been the causes of certain food-borne illnesses and spoilage (4). Native microflora of plants, presence of microorganisms in processing plant, air, dust, using contaminated water and animal/human excreta, preand post-harvest procedure including processing, storage, distribution, may be the sources of microbial contamination. Therefore, these may pose health trouble because they are often added to foods without supplementary processing or are eaten uncooked (5).

Due to increased use of drugs, microorganisms have become resistance to many antibiotics, as a result, use of drugs are increasing. So, it has become essential to find out new antimicrobial agents (6). Recently, there has been increasing interest in discovering new natural antimicrobials this is also has been true in food microbiology. Plant products with antimicrobial properties notably have obtained emphasis for a possible application in food production in order to prevent bacterial and fungal growth. Plant products are characterized for a wide range of volatile compounds, some of which are important flavor quality factor. Moreover, plant volatiles have been generally recognized as safe (GRAS) (1). Systematic screening for biological 
interactions between microorganisms and plant products has been valuable source of new and effective antimicrobial substances, which could have different action ways on/in the microbial cell when compared to other conventional antimicrobials. Plants synthesize by a secondary metabolism many compounds with complex molecular structures and some of them have been related with antimicrobial properties found in plant and their derivatives. Among these secondary metabolites are found alkaloids, flavonoids, isoflavonoids, tanins, cumarins, glycosides, terpens and phenolic compounds $(7,8)$.

In Bangladesh, although a lot of works has been conducted based on herbal plants and medicines, there is little information on the sources of contamination and antibacterial activity of spices. Based on this consideration the current study was designed to detect the microbial proliferation and assessment of antibacterial activity of various collected from various areas of Dhaka city, Bangladesh.

\section{MATERIALS AND METHODS}

Collection of samples \& processing. Sample of spices are collected for the detection of microbiological analysis and antibacterial activity from from Jatrabari bajar, Dhaka, Bangladesh within a period of July, 2017 to August, 2017. Samples were collected early in the morning and transported quickly to the laboratory according to the standard scheme. For preparing the sample suspension for microbiological examinations, $10 \mathrm{~g}$ of each sample was weighed and homogenized in $90 \mathrm{ml}$ normal saline to prepare $100 \mathrm{ml}$ sample suspension. Then, it was subjected to serial dilution (made up to $10^{-7}$ ) for microbiological analysis (9-13).

Total viable bacterial count (TVBC) and total fungal count. An aliquot of $0.1 \mathrm{ml}$ from $10^{-4}$ and $10^{-5}$ dilution of each sample was spread over nutrient agar (NA) for TVBC \& $0.1 \mathrm{ml}$ from $10^{-3}$ and $10^{-4}$ dilution was spread over SDA plate for the detection of total fungal load respectively $(10,11,14)$. Determination of Pseudomonas spp., Staphylococcus spp. and coliform bacteria. An aliquot of $0.1 \mathrm{ml}$ sample from $10^{-2} \& 10^{-3}$ dilution was spread on Cetrimide agar, MSA(Mannitol Salt Agar), MAC (MacConkey Agar) for the determination of Pseudomonas spp., Staphylococcus spp. And coliforms, respectively and incubated overnight at $37^{\circ} \mathrm{C}(11,12,15)$.
Detection of Vibrio spp., Salmonella spp., and Shigella spp. As Vibrio spp., Salmonella spp. and Shigella spp. remain in the environment as viable but nonculturable (VBNC) state, they do not appear readily during microbiological test procedures. Before conducting serial dilutions, $1 \mathrm{ml}$ of $10^{-1}$ and $10^{-2}$ diluted samples were enriched with alkaline peptone water (APW) for Vibrio spp. and selenite cystein broth (SCB) for Salmonella spp. \& Shigella spp. at $37^{\circ} \mathrm{C}$ for 2-4 hrs. The samples were then spread on the XLD agar and TCBS agar for detecting Salmonella spp., Shigella spp. and Vibrio spp. (small, yellow colored colony) $(11,12)$.

Determination of antibacterial activity of the spices. The antibacterial activity of the samples was carried out by using agar well diffusion method. At first, the suspension (with standard turbidity compared to that of McFarland standard of 0.5) of each of the test bacteria (Escherichia coli, Staphylococcus spp. Vibrio spp., Salmonella spp., Pseudomonas spp., Klebsiella spp., and Bacillus spp.) were spread evenly over the MHA using cotton swab which in turn resulted into uniform lawns. Wells made in the MHA was generated by cork-borer. Each of the samples then introduced separately in the specified well along with a positive

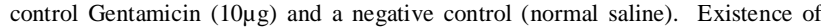
clear zone surrounding the sample solution (if any) was indicative of the presence of antibacterial activity of the samples tested $(10,11,16,17)$

\section{RESULTS}

Microbial analysis of spice samples. In the present study, total viable bacterial count (TVBC) was observed within the range of $10^{6}$ to $10^{7} \mathrm{cfu} / \mathrm{g}$. Among the specific bacterial isolates Staphylococcus spp., Escherichia coli and Pseudomonas spp. were found in almost all the samples within the margin of $10^{2}$ to $10^{6} \mathrm{cfu} / \mathrm{g}$. Alarmingly Salmonella spp. and Vibrio spp. were presumptively identified in one and two samples respectively. Besides every sample showed the presence of fungal load up to $10^{3} \mathrm{cfu} / \mathrm{g}$ (table 1$)$.

Antibacterial activity of spices (crude extraction). Antibacterial activity of these samples was tested against seven laboratory isolates. Syzygium aromaticum showed highest activity against as many as five bacterial isolates followed by Cinnamomum verum which was effective against four isolates. On the other contrary, both Zingiber officinale and Laurus nobilis demonstrated their antibacterial activity only against Staphylococcus spp. and Klebsiella spp. respectively (table 2).

TABLE 1. Microbiological analysis of different spice samples

\begin{tabular}{lccccccc}
\hline \multicolumn{1}{c}{ Sample } & TVBC & Fungi & E. coli & $\begin{array}{c}\text { Staphylococcus } \\
\text { spp. }\end{array}$ & $\begin{array}{c}\text { Pseudomonas } \\
\text { spp. }\end{array}$ & $\begin{array}{c}\text { Salmonella } \\
\text { spp. }\end{array}$ & $\begin{array}{c}\text { Vibrio } \\
\text { spp. }\end{array}$ \\
\hline Zingiber officinale 1 & $2.26 \times 10^{7}$ & $7.1 \times 10^{3}$ & $1.3 \times 10^{4}$ & $1.46 \times 10^{6}$ & $3.1 \times 10^{5}$ & $3 \times 10^{3}$ & $\mathrm{Nil}$ \\
Zingiber officinale 2 & $3.3 \times 10^{6}$ & $3 \times 10^{2}$ & $2.4 \times 10^{4}$ & $1.0 \times 10^{5}$ & $3 \times 10^{4}$ & $\mathrm{Nil}$ & $\mathrm{Nil}$ \\
Cinnamomum verum 1 & $3.41 \times 10^{6}$ & $6.1 \times 10^{2}$ & $1.6 \times 10^{4}$ & $1.28 \times 10^{5}$ & $8 \times 10^{4}$ & $\mathrm{Nil}$ & $4 \times 10^{3}$ \\
Cinnamomum verum 1 & $4.5 \times 10^{6}$ & $3.1 \times 10^{2}$ & $2.8 \times 10^{3}$ & $2.0 \times 10^{5}$ & $4 \times 10^{4}$ & $\mathrm{Nil}$ & $\mathrm{Nil}$ \\
Syzygium aromaticum 1 & $2.27 \times 10^{6}$ & $4.3 \times 10^{2}$ & $4.9 \times 10^{3}$ & $3.7 \times 10^{5}$ & $5.2 \times 10^{4}$ & $\mathrm{Nil}$ & $\mathrm{Nil}$ \\
Syzygium aromaticum 2 & $1.46 \times 10^{6}$ & $1.1 \times 10^{2}$ & $4.6 \times 10^{3}$ & $1.8 \times 10^{5}$ & $2.3 \times 10^{4}$ & $\mathrm{Nil}$ & $\mathrm{Nil}$ \\
Laurus nobilis 1 & $2.9 \times 10^{7}$ & $5.7 \times 10^{3}$ & $4.9 \times 10^{4}$ & $2.3 \times 10^{5}$ & $6.4 \times 10^{5}$ & $\mathrm{Nil}$ & $2.1 \times 10^{3}$ \\
Laurus nobilis 2 & $5.4 \times 10^{6}$ & $2.9 \times 10^{2}$ & $6.6 \times 10^{3}$ & $1.5 \times 10^{5}$ & $2 \times 10^{4}$ & $\mathrm{Nil}$ & $\mathrm{Nil}$ \\
\hline
\end{tabular}

TVBC $=$ Total viable bacterial count

Maximum limit (cfu/g) of microorganisms in spices: (According to ICMSF: 1998)

- total viable bacterial count (TVBC): $10^{6} \mathrm{cfu} / \mathrm{g}$

- fungi: $10^{4} \mathrm{cfu} / \mathrm{g}$

- Coliforms and E. coli: $10^{3} \mathrm{cfu} / \mathrm{g}(18)$ 
TABLE 2. Antibacterial activity of spices through crude extraction method: zone of inhibition (mm)

\begin{tabular}{|c|c|c|c|c|c|c|c|}
\hline \multirow[b]{2}{*}{ Sample } & \multicolumn{7}{|c|}{ Zone of inhibition (mm) } \\
\hline & E. coli & $\begin{array}{c}\text { Staphylococcus } \\
\text { spp. }\end{array}$ & $\begin{array}{c}\text { Bacillus } \\
\text { spp. }\end{array}$ & $\begin{array}{c}\text { Salmonella } \\
\text { spp. }\end{array}$ & $\begin{array}{l}\text { Vibrio } \\
\text { spp. }\end{array}$ & $\begin{array}{c}\text { Pseudomonas } \\
\text { spp. }\end{array}$ & $\begin{array}{c}\text { Klebsiella } \\
\text { spp. }\end{array}$ \\
\hline Zingiber officinale & 0 & 10 & 0 & 0 & 0 & 0 & 0 \\
\hline Cinnamomum verum & 12 & 20 & 0 & 0 & 0 & 15 & 10 \\
\hline Syzygium aromaticum & 13 & 20 & 15 & 12 & 0 & 0 & 20 \\
\hline Laurus nobilis & 0 & 0 & 0 & 0 & 0 & 0 & 17 \\
\hline $\begin{array}{l}\text { Positive control } \\
\text { (Gentamicin) }\end{array}$ & 17 & 15 & 14 & 18 & 14 & 16 & 18 \\
\hline $\begin{array}{l}\text { Negative Control } \\
\text { (Normal saline) }\end{array}$ & 0 & 0 & 0 & 0 & 0 & 0 & 0 \\
\hline
\end{tabular}

By analyzing the results, mostly spices have antibacterial activity against Klebsiella spp. Salmonella spp. Pseudomonas spp, Staphylococcus spp. and Bacillus spp. when comparing with the clear zone of the positive control Gentamicin $(10 \mu \mathrm{g})$ as standard ( $\geq 15 \mathrm{~mm}$ ) (18). Antibacterial activity was found for three samples against Vibrio spp. and little was shown against $E$. coli and Vibrio spp.

In each experiment, both the positive control Gentamicin $(10 \mu \mathrm{g})$ and the negative control of normal Saline. In all the cases, Gentamicin $(10 \mu \mathrm{g})$ produced zone of inhibition around $15-18 \mathrm{~mm}$ against all the laboratory isolates and the negative controls didn't show zone of inhibition at all (18).

\section{DISCUSSION}

Medicinal plants play a vital role for the development of new drugs. Spices may be contaminated because of the surroundings under which they were cultivated and harvested. During harvesting spices may have come in contact with various types of microorganisms which may cause certain food-borne illnesses and spoilage although, during cleaning and processing procedure of spices, there is progressive reduction in the number and types of microorganisms (4). Therefore current study was designed for analyzing the microbiological profiling of the spice samples collected from various areas of Dhaka city, Bangladesh and also to determine their antibacterial activity against seven laboratory isolates.

Presence of pathogenic and spoiling microorganisms in spices could act as vehicles for microorganisms to enter in foods. Frequently, spices are grown and harvested in warm and humid areas where the growth of wide variety of microorganisms is readily supported. As many other agricultural commodities, spices are exposed to a wide range of environmental microbial contamination during harvest, processing, and in retail markets by dust, waste water, and animal and even human excreta (1).
The International Commission on Microbiological Specifications for Foods (1998) has set up maximum limit of $10^{6}, 10^{4}$ and $10^{3} \mathrm{CFU}$ of total aerobic mesophilic bacteria (TAMB), fungi, coliforms and $E$. coli, respectively for per gram of spice. Previous studies on the microbiology of spices have demonstrated profiles of microorganisms, including total heterotrophs, Bacillus cereus, Clostridium perfringens, Escherichia coli, Salmonella and toxigenic moulds. In many of the spicegrowing countries, spices are often sundried after harvesting by spreading them on open field and then sold without any treatment in order to reduce the microbial load. Thus, it is expected that spices sold in these areas contain a more or less or "original" microflora. $(4,5)$. From the table 1 of microbial load it can be observed that total viable bacteria were present for all the samples. Besides Pseudomonas, E. coli and Staphylococcus spp. were also found for all the samples. As it is known that Staphylococcus spp. is a normal flora of skin, so may be the sample was contaminated from skin flora (table: 1). Besides the load of fungus in these samples was also marginal according to the guideline provided by ICMSF, 1998 (18). Sometime spices are consumed in unprocessed condition, as mouth freshener so it should not contain the level of microorganism that may pose health risk.

Crude extract of most of the samples gave clear zone against the tested laboratory isolates (Table 2). The clear zone was better for Staphylococcus spp. and Klebsiella spp. The best antibacterial activity against five bacterial isolates was shown by Syzygium aromaticum followed by Cinnamomum verum that showed activity against four isolates. On the other hand, Vibrio spp. were found to be the most resistant isolate against the crude extracts of these samples.

\section{CONCLUSIONS}

Use of spices as microbial growth inhibitor in foods is often limited because of flavor considerations as effective antimicrobial dose may exceed the organoleptically accepted level. Nonetheless, combinations of spices and 
other antimicrobial barriers could enhance the food shelf stability and microbial safety even in moderated levels. Due to this and due to the fact that spices are as GRAS, the antimicrobial properties of spices continue to be of interest (1). It is established that spices and their derivatives could be suitable alternatives for inclusion in food conservation systems and could act sometimes as main or adjuvant antimicrobial compounds. Before including spices and/or their derivatives in food conservation systems, some evaluations about microbiological quality, economic feasibility and antimicrobial effect for a long time and toxicity should be carried out.

\section{REFERENCES}

4. de Souza EL, Stamford TLM, Lima EO, Trajano VN, Filho JMB. 2005. Antimicrobial effectiveness of spices: an approach for use in food conservation systems. Braz. arch. biol. technol. 48 (4). http://dx.doi.org/10.1590/S1516-89132005000500007

5. Selvamohan T, Ramadas V, Kishore SS. 2012. Antimicrobial activity of selected medicinal plants against some selected human pathogenic bacteria. Adv. Appl. SciRes. 3 (5): 3374-3381.

6. Mishra RP, Sharma K. 2014. Antimicrobial activities of Syzigiumaromaticum. (Clove)- Int. Res. J. BioSci. 3 (8): 22-25.

4. Ahene RE, Odamtten GT, Owusu E. 2011. Fungal and bacterial contaminants of six spices and spice products in Ghana. Afri. J. of Environ. Sci Tech. 5 (9): 633-640

5. Colak H, Bingol EB, Hampikyan H, Nazli B. 2006. Determination of aflatoxin contamination in red-scaled, red and black pepper by ELISA and HPLC. J. Food Drug Anal. 14 (3): 292-296.

6. Pandey A, Singh P. 2011. Antibacterial activity of Syzygium aromaticum (clove) with metal ion, effect against food borne pathogens Asian J. Plant Sci. Res. 1: 69-80.
7. Hoque MM, Bari ML, Juneja VK, Kawamoto S. 2008. Antimicrobial activity of clove and cinnamon extract against food borne pathogens and bacteria with their essential oils. Rep. Nat. Food Res. Inst. 72: 9-21.

8. Gutierrez J, Barry-Ryan C, Bourke P. 2009. Antimicrobial activity of plant essential oils using food model media: Efficacy, synergistic potential and interactions with food components. Food Microbiol. 26 (2): 142-150.

9. Sharmin M, Nur IT, Acharjee M, Munshi SK, Noor R. 2014 Microbiological profiling and the demonstration of in vitro anti-bacterial traits of the major oral herbal medicines used in Dhaka Metropolis. SpringerPlus. 3: 739 .

10. Feroz F, Das JS, Tahera J, Das KK, Noor R. 2014. Investigation of microbiological spoilage and demonstration of the anti-bacterial activity of the major imported fruits within Dhaka Metropolis. S. J. Microbiol. 4 (1): $1-4$.

11. Das JS, Feroz F, Tahera J, Das KK, Noor R. 2014. Assessment of microbiological contamination and the in vitro demonstration of the anti-bacterial traits of the commonly available local fruit blend within Dhaka Metropolis. J. Pharmacog. Phytoche. 3 (1): 73-77.

12. Cappuccino JG, Sherman N. 1996. Microbiology - A laboratory manual The Benjamin/Cummings Publishing Co., Inc., Menlo Park, California.

13. American Public Health Association (APHA). 1998. Standard methods for the examination of water and wastewater. American Public Health Association, Washington, D.C.

14. Sultana T, Rana J, Chakraborty SR, Das KK, Rahman T, Noor R. 2014 Microbiological analysis of common preservatives used in food items and demonstration of their in vitro anti-bacterial activity. Asian Pac. J. Tropi. Dis. 4 (6): $452-456$

15. Akon T, Das KK, Naher LN, Noor R. 2015. Demonstration of in vitro antibacterial activity of the popular cosmetics items used by the Dhaka locality. Asian Paci. J. of Tropi. Dis. 5 (1): S121-S126.

16. Jagessar RC, Mars A, Gones G. 2008. Selective antimicrobial properties of leaf extract against various micro-organisms using disc diffusion and agar well diffusion method. J. Nat. Sci. 6 (2): 24-38.

17. Hussain A, Wahab S, Zarin I, Hussain MDS. 2010. Antibacterial activity of the leaves of Coccinia indica (W. and A) of India. Adv. Biol. Res. 4: $241-8$

18. ICMSF. 1998. Microorganisms in Foods. Sampling for Microbiological Analysis: Principles and Specific Applications, Second edition. University of Toronto Press, Toronto. 